Geo-Marine Letters

Volume 27, Numbers 2-4 / juin 2007: 249-257

http://dx.doi.org/ 10.1007/s00367-007-0081-3

(C2007 Springer Science+Business Media
Archimer, archive institutionnelle de l'Ifremer http://www.ifremer.fr/docelec/

\title{
Authigenic carbonates from methane seeps of the Congo deep-sea fan
}

\author{
Catherine PIERRE ${ }^{1, *}$ and Yves FOUQUET ${ }^{2}$ \\ ${ }^{1}$ LOCEAN, UPMC (UMR 7159), 4 Place Jussieu, 75252 Paris Cedex 05, France \\ ${ }^{2}$ Géosciences Marines, IFREMER, Technopôle de I'Iroise, 29280 Plouzané Cedex, France \\ communicating author : e-mail : cat@locean-ipsl.upmc.fr; tel: 33144275162; fax : 33144277159
}

\begin{abstract}
:
Submersible investigations with the ROV Victor 6000 of some pockmark structures on the seafloor of the Congo deep-sea fan have shown that they are active venting sites of methane-rich fluids, associated with abundant fauna and carbonate crusts. Moreover, methane hydrates have been observed both outcropping and deep in the sediments in the centre of the "Regab" giant pockmark. Authigenic carbonates, mostly calcite sometimes mixed with aragonite, are cementing the sedimentary matrix components and fauna; diatoms are abundant but only as moulds, indicating that biogenic silica dissolution occurred in situ synchronous with carbonate precipitation. The occurrence of diagenetic barite and pyrite in some carbonate crusts demonstrates that they can be formed either within the sulphate/methane transition zone or deeper in sulphate-depleted sediments. The oxygen isotopic compositions of the diagenetic carbonates (3.17-6.01\% V-PDB) indicate that precipitation occurred with bottom seawater mixed with a variable contribution of water from gas hydrate decomposition. The very low carbon isotopic compositions of the diagenetic carbonates ( -57.1 to $-27.75 \%$ V-PDB) demonstrate that carbon derives mostly from the microbial oxidation of methane.
\end{abstract}

Keywords: authigenic carbonate, methane seep, gas hydrate, Congo deep-sea fan, carbon isotopes, oxygen isotopes 


\title{
AUTHIGENIC CARBONATES FROM METHANE-SEEPS OF THE CONGO DEEP-SEA FAN
}

\author{
Catherine PIERRE ${ }^{1}$ and Yves FOUQUET ${ }^{2}$ \\ ${ }^{1}$ LOCEAN, UPMC (UMR 7159), 4 Place Jussieu, 75252 Paris Cedex 05, France \\ ${ }^{2}$ Géosciences Marines, IFREMER, Technopôle de l'Iroise, 29280 Plouzané Cedex, France \\ communicating author : \\ e-mail : cat@locean-ipsl.upmc.fr; tel: 33144275162; fax : 33144277159
}

\begin{abstract}
Submersible investigations with the ROV-Victor 6000, of some pockmark structures on the seafloor of the Congo deep-sea fan have shown that they are active venting sites of methanerich fluids associated with abundant fauna and carbonate crusts. Moreover, methane hydrates have been observed both outcropping and deep in the sediments in the center of the "Regab" giant pockmark. Authigenic carbonates, mostly calcite sometimes mixed with aragonite are cementing the sedimentary matrix components and fauna; diatoms are abundant but only as molds indicating that biogenic silica dissolution occurred in situ just before carbonate precipitation. The occurrence of diagenetic barite and pyrite in some carbonate crusts demonstrates that they can be formed either within the sulfate/methane transition zone or deeper in sulfate depleted sediments. The oxygen isotopic compositions of the diagenetic carbonates (3.17 to $6.01 \%$ V-PDB) indicate that precipitation occurred with bottom seawater mixed with a variable contribution of water from gas hydrates decomposition. The very low carbon isotopic compositions of the diagenetic carbonates (-57.1 to $-27.75 \%$ V-PDB) demonstrate that carbon derives mostly from the microbial oxidation of methane.
\end{abstract}

Key words: authigenic carbonate, methane seep, gas hydrate, Congo deep-sea fan, carbon isotopes, oxygen isotopes

\section{INTRODUCTION}

In cold seep marine environments, methane contained in the ascending fluids is oxidized as $\mathrm{CO}_{2}$ by a microbial consortium of sulfate reducing bacteria and methanotrophic archea (e.g. Boetius et al., 2000; Elvert et al., 2000; Orphan et al., 2001; Valentine and Reeburgh, 2000). The $\mathrm{CO}_{2}$ released during this process of anaerobic oxidation of methane (AOM) is then mostly precipitated as authigenic carbonates, which form crusts and concretions within the anoxic sediments. These carbonates represent preserved archives of the AOM process and their mineralogy, geochemical and isotopic compositions provide vast information about the composition and origin of the fluids from which they have precipitated.

Various examples of authigenic carbonates from marine cold seeps have been studied worldwide in modern and past sedimentary successions (e.g. Aloisi et al., 2000; Bohrmann et al., 1998 ; Campbell et al., 2002 ; Mazzini et al., 2004 ; Peckmann et al., 2001; Peckmann and Thiel, 2004; Ritger et al., 1987; Stadnitskaia et al., 2005). The main characteristic of these carbonates is their very low ${ }^{13} \mathrm{C}$ values (down to $-62 \%$ V-PDB), which rely on the methane source of carbon.

We report new data on authigenic carbonate occurrences from giant pockmarks related to shallow gas and oil reservoirs that are located in the Congo deep-sea fan (Gay et al., 2003, Ondreas et al., 2005). The aims of this study were to verify if the carbonates associated with these pockmarks were precipitated via AOM process and if they record any evidence of the presence of gas hydrates which are very abundant at some of these sites. 


\section{GEOLOGICAL SETTING}

The pelagic sediments covering the Congo deep-sea fan are stacked buried channellevee systems, which have deposited turbiditic sequences up to several $\mathrm{km}$-thick since the early Miocene (Savoye et al., 2000; Séranne et al., 1992). These sediments are mostly composed of silty to sandy clays containing abundant diatoms and 10 to 20 weight $\%$ pelagic carbonate (mostly coccolites). Organic content is relatively high (3 to 5 weight $\%$ on average, Khripounoff, unpublished data) originating both from high surface productivity due to huge nutrients inputs from the Congo river plume, and from terrestrial organic matter transported by the Congo river. Due to the massive terrestrial inputs by the Congo river discharge, the sedimentation rates in this area reach 10 to $20 \mathrm{~cm} / \mathrm{k} . \mathrm{y}$. (Ondréas et al., 2005).

\section{MATERIAL AND METHODS}

The sedimentary material was collected at three sites (Fig. 1) with the ROV-VICTOR during the oceanographic cruise ZAIROV-2 (2000) as a part of the ZAIANGO project (joint project IFREMER-TOTAL, Savoye et al., 2000). At the diving sites BSR (water depth: 650 $\mathrm{m}$ ), Astrid (water depth: $2830 \mathrm{~m}$ ) and Regab (water depth: $3150 \mathrm{~m}$ ), the carbonate crusts and concretions are associated with macrofauna (Fig. 2); the dominant species correspond to Siboglinidae tubeworms and giant bivalves (Vesicomyidae Calyptogena and Mytilidae Bathymodiolus) (Ondréas et al., 2005). The active fluid seepage zones are characterized by patches of microbial mat comprising white sulfur oxidizing Beggiatoa mat surrounded by black reduced sediments. At a few places, seepage of oily bubbles and massive gas hydrates were observed directly at the seafloor as well as in the underlying sediments (Charlou et al., 2004; Ondreas et al., 2005).

For this study, we selected twenty samples of carbonate crusts and concretions of various lithofacies (Table 1). A fragment of several $\mathrm{cm}^{3}$ was separated from each sample, dried at $60^{\circ} \mathrm{C}$, and powdered in an agate mortar. The mineralogical, geochemical and isotopic analyses were performed on the same powder; prior to isotopic analyses, the powder was rinsed with distilled water to remove any trace of salts.

The mineralogy and geochemical compositions of the diagenetic carbonates have been determined by $\mathrm{X}$ ray diffraction (XRD) and X ray fluorescence (XRF) respectively, and have been combined with scanning electron microscope (SEM) observations.

The oxygen and carbon isotopic compositions of carbonates have been measured to characterize the water and carbon sources of the fluids from which the carbonates precipitated. They are expressed in the conventional notation defined as:

$=[(\mathrm{Rs} / \mathrm{Rr})-1] * 1000$, where $\mathrm{R}={ }^{18} \mathrm{O} /{ }^{16} \mathrm{O}$ or ${ }^{13} \mathrm{C} /{ }^{12} \mathrm{C}$ respectively in the sample (Rs) and in the reference $(\mathrm{Rr})$. The reference for ${ }^{18} \mathrm{O}$ and ${ }^{13} \mathrm{C}$ is the V-PDB (Craig, 1957; Gonfiantini et al., 1995). The $\mathrm{CO}_{2}$ gas extracted from the carbonate by attack with $100 \%$ phosphoric acid at $25^{\circ} \mathrm{C}$ was analysed with a triple collector mass spectrometer (VG Sira 9). The analytical precision 2 is $0.01 \%$ or both ${ }^{18} \mathrm{O}$ and ${ }^{13} \mathrm{C}$; the reproducibility is $\pm 0.05 \%$ o for both ${ }^{18} \mathrm{O}$ and ${ }^{13} \mathrm{C}$.

The analytical results are reported in Table 1.

\section{RESULTS}

\section{4-1: Petrography and mineralogy}

The authigenic carbonates occur generally as medium grey in color, massive or vacuolar hard crusts cementing the fauna and forming relatively flat pavements of several $\mathrm{cm}$ up to a few meters thick, which cover hundreds $\mathrm{m}^{2}$ of the seafloor; other carbonate lithofacies correspond to compact $\mathrm{cm}$ to $\mathrm{dm}$ sized concretions corresponding to indurated burrows (Fig. 
3). Many authigenic carbonates were precipitated within the sediments and their outcrop at the seafloor indicates that they were exhumed due to erosion of overlying soft sediments by deep currents activity and possibly by active methane discharge.

Three main morphological types of crusts were identified: (1) carbonate-associated with bivalve shells (Fig. 3A), (2) partly buried massive carbonates (Fig. 3B), and (3) carbonates fossilizing fluid conduits within the sediment (Fig. 3C and 3D). The carbonates that fossilize and cement the shells are composed primarily of calcite and $\mathrm{Mg}$-calcite. The frequent occurrence of aragonite is mainly related to shell fragments (mussels or Vesicomyidae) included in the samples; however, aragonite is also present as large palissadic acicular crystals (Fig. 4c). The massive crusts, by contrast, are composed mainly of $\mathrm{Mg}$-calcite, barite $\left(\mathrm{BaSO}_{4}\right)$ occurring as a trace mineral only. Carbonates are totally absent in the reduced sediments surrounding the carbonate crusts. In areas of massive gas hydrates, the sediments are composed mainly of quartz, kaolinite and halloysite, and show the highest pyrite and pyrrhotite contents, thus indicating extreme reducing conditions. Millimetre-length Mg-calcite and aragonite grains occur within these sediments. Quartz, kaolinite and smectite are also found in the black anoxic sediments surrounding the carbonate crusts, indicating that these sediments are mainly detrital in origin. Pyrite appears to be related to iron reduction in association with microbial activity.

The sulfur content of the anoxic sediments is very low $(<0.7 \%)$, especially at sites where no crust is observed. By contrast, in or near the sediments containing carbonate crusts, sulfur contents are higher, varying in the range 1.5 to $3.4 \%$. The highest sulfur content $(3.4 \%)$ was measured in the pockmark centre in sediments associated with carbonate crusts, often accompanied by the release of methane hydrates and few bubbles. These bubbles, with oily appearance, were only observed at one spot and not sampled. Sulfide levels correlate relatively well with the presence of pyrite. Otherwise, no oil was observed in the sediments or carbonates of the pockmark.

The microfacies observed with SEM reveal abundant molds of diatoms, which indicate active dissolution of biogenic silica synchronous with carbonate precipitation (Fig. 4b). Calcite and aragonite euhedral crystals are often associated with pyrite crystals ( $\sim \mathrm{m}$ sized) either isolated or clustered in framboids (Fig. 4a, d). In the Astrid and Regab pockmarks, authigenic barite is also present as radiating acicular crystals associated with the carbonate minerals (Fig. 4b). Since barite is absent in the surrounding sediments, it is postulated that barium is brought by the diagenetic fluids.

\section{3-2: Geochemical composition}

Major and trace element analyses were performed on samples using X-Ray fluorescence techniques. Results of analyses are presented in Table 1. Calcium concentration is between 37 and 53\%. Massive carbonates, primarily made of Mg-calcite, have $\mathrm{Mg}$ concentration close to $5 \%$. In the mixture of carbonate and shells where aragonite dominates over the other carbonates, $\mathrm{Mg}$ concentrations are much lower, generally less than $1 \%$. Fe and $\mathrm{Mn}$ are at extremely low concentrations. Concentrations of $\mathrm{SiO}_{2}(2$ to $13 \%)$ and $\mathrm{Al}_{2} \mathrm{O}_{3}(0.9$ to $4 \%)$ are indicative of small and variable proportions of clay minerals and quartz from the sediment incorporated during crust formation. Surrounding sediments are characterized by relatively homogeneous concentrations in $\mathrm{SiO}_{2}$ (41 to 44\%) and $\mathrm{Al}_{2} \mathrm{O}_{3}$ (15 to 20\%). Barium concentration ranges between 53 and $75817 \mathrm{ppm}$ and is directly related to the occurrence of barite.

\section{3-3: Oxygen and carbon stable isotopes:}

The isotopic compositions of the authigenic carbonate crusts and concretions from the Congo deep-sea fan show a very large dispersion (Fig. 5) that reflects the great variability of 
the composition of the fluids where carbonate precipitation occurred. The two samples from the BSR site exhibit the lowest ${ }^{18} \mathrm{O}$ values $\left(3.17 \%\right.$ and $4.00 \%$ ) and the highest ${ }^{13} \mathrm{C}$ values ($35.68 \%$ and $-27.75 \%$ ). For samples from the Regab and Astrid sites, two groups of values may be identified : one group is constituted only by $\mathrm{Mg}$-calcite and exhibits a narrow range of isotopic values with the highest ${ }^{18} \mathrm{O}$ values $\left(5.29<{ }^{18} \mathrm{O} \%\right.$ o $\left.\mathrm{V}-\mathrm{PDB}<6.01\right)$ and very low ${ }^{13} \mathrm{C}$ values $\left(-58.48<{ }^{13} \mathrm{C} \% \mathrm{~V}-\mathrm{PDB}<-50.68\right)$; the other group composed of mixtures in variable proportions of calcite and aragonite, shows a larger range of isotope values $\left(3.57<{ }^{18} \mathrm{O} \%\right.$ V-PDB $<4.83 ;-57.2<{ }^{13} \mathrm{C} \%$ V-PDB $\left.<-46.1\right)$.

The average isotopic compositions of bulk carbonate in the sediments from outside the pockmarks ( ${ }^{18} \mathrm{O}=0.6 \%$ V-PDB, ${ }^{13} \mathrm{C}=1.0 \% \mathrm{~V}$-PDB) are completely different from those of the authigenic carbonates. This is easily explained because the bulk carbonate fraction is composed essentially by coccolites produced by photosynthetic algaes living in the surface waters. The bulk carbonate ${ }^{18} \mathrm{O}$ and ${ }^{13} \mathrm{C}$ values record the warm temperatures $\left(26 \pm 2{ }^{\circ} \mathrm{C}\right)$, and the isotopic compositions ( ${ }^{18} \mathrm{O}=0.8$ to $1.0 \%$ o-SMOW; ${ }^{13} \mathrm{C}=1.2$ to $1.5 \% \mathrm{~V}$-PDB) of the superficial equatorial western Atlantic waters (Vangriesheim and Pierre, unpublished data from Biozaire 3 cruise).

\section{DISCUSSION}

\section{4-1 : Cold seep related diagenesis}

The mineralogy of the authigenic carbonate crusts and concretions from cold seeps of the Congo deep-sea fan is dominated by Mg-calcite with minor amounts of aragonite, these calcium carbonates being generally the most common minerals precipitated in sediments where pore fluids contain sulfate ions though to inhibit dolomite precipitation (Baker and Kastner, 1981). There are different factors considered to favor precipitation of calcite over aragonite in seawater, such as low sulfate and $\mathrm{Mg}$ concentrations (Tucker and Wright, 1990) and a strong temperature effect with increasing calcite precipitation rates and decreasing aragonite precipitation rates at low temperatures (Burton and Walter, 1987). Because bottom seawater is very cold (lower than $5^{\circ} \mathrm{C}$, see below) in the deep Atlantic Ocean, it is more probable that temperature exerts the dominant control on the carbonate mineralogy of the carbonate crusts precipitating at the seafloor.

Another important diagenetic reaction concerns dissolution of biogenic silica as revealed by the abundance of diatom molds in the authigenic carbonates, which indicates that the two processes of amorphous silica dissolution/carbonate precipitation were coupled. This can be explained by AOM that increases $\mathrm{pH}$ and alkalinity in pore waters and thus changes silica and carbonate saturation levels.

Barite and pyrite are also diagenetic minerals that are frequently observed associated with authigenic carbonates from cold seeps. Barite represents a conspicuous mineral precipitating within the sediments in the sulfate/methane transition zone i.e. at the boundary between sulfate rich and sulfate depleted solutions (Fu et al., 1994; Torres et al., 1996; Aloisi et al., 2004; Castellini et al., 2006; Riedinger et al., 2006). Pyrite is related to bacterial sulfate reduction in anoxic sediments. The presence of sulfate and sulfide minerals in association with the diagenetic carbonates argues for the upward flux of barium by ascending fluids and for the downward flux of sulfate from the bottom seawater to the sediment where it is progressively reduced to sulfide by microbial activity.

\section{4-2: Characterization of the diagenetic fluids}

The oxygen isotopic composition of carbonates depends on the temperature and on the oxygen isotopic composition of the water, as well as on the mineralogy. The fractionation 
factor for the calcite-water system is defined by the thermodynamic equation of Anderson and Arthur (1983). For the aragonite-water system, the equilibrium ${ }^{18} \mathrm{O}$ values of aragonite were calculated using the equation of Grossman and $\mathrm{Ku}$ (1986).

These equations were used to estimate the ${ }^{18} \mathrm{O}$ values of the carbonate minerals precipitated at isotopic equilibrium with ambient conditions. The temperature of the bottom seawater at cold seep sites in the Congo deep-sea fan ranges between $5^{\circ} \mathrm{C}$ at the depth of BSR site and $2.5^{\circ} \mathrm{C}$ at the depth of Astrid and Regab sites; the ${ }^{18} \mathrm{O}$ value of the bottom seawater averages $0.2 \%$ V-SMOW (Vangriesheim and Pierre, unpublished data). For this we have estimated the equilibrium ${ }^{18} \mathrm{O}$ values for calcite (2.5 to $3.1 \%$ V-PDB) and for aragonite (3.6 to $4.2 \% \mathrm{~V}-\mathrm{PDB}$ ) in the temperature range from $5^{\circ} \mathrm{C}$ to $2.5^{\circ} \mathrm{C}$. Departure from these values would indicate precipitation with fluids different from ambient bottom seawater.

The carbon isotopic compositions of diagenetic carbonates are related to the inputoutput balance of the inorganic and organic sources of carbon which controls the carbon isotopic composition of the total dissolved inorganic carbon reservoir of the pore fluids where carbonate precipitation occurs. In organic-rich sediments, the microbial processes dominate; when sulfate is present, its reduction by bacteria is fueled either by organic matter or by methane (or other hydrocarbons), following reactions (1) or (2).

$2 \mathrm{CH}_{2} \mathrm{O}+\mathrm{SO}_{4}^{2-}>2 \mathrm{HCO}_{3}^{-}+\mathrm{H}_{2} \mathrm{~S}$
$\mathrm{CH}_{4}+\mathrm{SO}_{4}^{2-}>\mathrm{HCO}_{3}^{-}+\mathrm{HS}^{-}+\mathrm{H}_{2} \mathrm{O}$

The increase of pore water alkalinity due to the addition of bicarbonate ions by these reactions enhances precipitation of authigenic carbonate. The produced $\mathrm{HCO}_{3}{ }^{-}$is depleted in ${ }^{13} \mathrm{C}$ because carbon originates from ${ }^{13} \mathrm{C}$-depleted sources, organic matter $\left({ }^{13} \mathrm{C} \sim-25 \%\right.$ o $\mathrm{V}$-PDB ) and methane $\left(-110<{ }^{13} \mathrm{C} \% \mathrm{~V}-\mathrm{PDB}<-50\right.$ for bacterial methane and $-50<{ }^{13} \mathrm{C} \% \mathrm{~V}-\mathrm{PDB}<$ -20 for thermogenic methane; Whiticar, 1999). During reaction (2), which corresponds to anaerobic oxidation of methane (AOM) coupled with bacterial sulfate reduction (BSR), there is a kinetic isotope fractionation by which the preferential oxidation of ${ }^{12} \mathrm{C}$-rich methane $\left(1.002<\mathrm{CH}_{4}-\mathrm{CO}_{2}<1.014\right.$; Whiticar and Faber, 1986; Alperin et al., 1988) causes the progressive ${ }^{13} \mathrm{C}$ enrichment in the remaining methane as the reaction progresses. Hydrogen sulfide as a byproduct of bacterial sulfate reduction generally precipitates as pyrite or other metallic sulfides depending on the availability of metal ions in pore solutions.

The ${ }^{18} \mathrm{O}$ values of authigenic carbonates from the Congo deep-sea fan indicate that they have precipitated either with the bottom seawater or in ${ }^{18} \mathrm{O}$-rich waters. The ${ }^{18} \mathrm{O}$ enrichment reaches 2 to $3 \%$ for the highest ${ }^{18} \mathrm{O}$ values of Regab and Astrid sites, which fall outside the range of equilibrium values calculated for calcite and aragonite. In the deep-sea environment, the source of ${ }^{18} \mathrm{O}$-rich waters may come from the dehydration of clay minerals or from the decomposition of gas hydrates. Although the first possibility cannot be excluded, the second hypothesis seems to be more realistic in the case of the sites studied in the Congo deep-sea fan where gas hydrates have been observed outcropping at the seafloor and buried within the sediments.

The very low ${ }^{13} \mathrm{C}$ values of the authigenic carbonates testify in favor of methane as the major source of carbon, oxidized as $\mathrm{CO}_{2}$ by methanotrophic archaea. However, at the BSR site, which is relatively shallow and close to the continent, there is probably a significant contribution of carbon from organic matter oxidation to explain the ${ }^{13} \mathrm{C}$-enrichment of the authigenic carbonates. Gas hydrate sampled at the Regab site presents a hydrocarbon gas composition and methane isotopic compositions ( ${ }^{2} \mathrm{H}=-199 \%$ V-SMOW; ${ }^{13} \mathrm{C}=-69.3 \% \mathrm{~V}$ - 
PDB) characteristic of methane produced by microbial $\mathrm{CO}_{2}$ reduction (Charlou et al., 2004). This oxidized methane would precipitate carbonate cement with a ${ }^{13} \mathrm{C}$ value between -59 and $-71 \% \mathrm{~V}-\mathrm{PDB}$, if we use the two extreme values of $\mathrm{CH}_{4}-\mathrm{CO}_{2}$ and a carbon isotope enrichment factor of $12 \%$ between $\mathrm{CO}_{2}$ and solid carbonate (Bottinga, 1969). The carbonate nodules that were extracted from the gas hydrate sediments have a ${ }^{13} \mathrm{C}$ value of $-48.42 \% \mathrm{~V}$ PDB; these nodules are composed by a mixture of carbonates since authigenic carbonate cements the sediments that contain a fraction of pelagic carbonate. The mass balance calculation shows that the difference of $20 \%$ between methane and the carbonated nodule may be explained by the mixing of authigenic cement ( ${ }^{13} \mathrm{C} \sim-60 \%$ V-PDB) with sediment containing about $20 \%$ of pelagic carbonate $\left({ }^{13} \mathrm{C} \sim 1.0 \%\right.$ V-PDB), these estimations being consistent with the observations.

There is also an obvious trend between increasing ${ }^{18} \mathrm{O}$ values and decreasing ${ }^{13} \mathrm{C}$ values in $\mathrm{Mg}$-calcites which tends to confirm that the decomposition of gas hydrates liberated ${ }^{18} \mathrm{O}$-rich water and methane that was oxidized by archaea to form $\mathrm{CO}_{2}$, further precipitated as carbonate.

\section{CONCLUSIONS}

The authigenic carbonates from cold seeps of the Congo deep-sea fan provide a new example of carbonate mineralization related to microbial activity fueled by methane from venting fluids. They show numerous similarities but also specific characteristics compared to the authigenic carbonates from other methane seep sites. During diagenesis, the sedimentary matrix was cemented by carbonate, with the exception of diatoms that were completely digested but always remain visible as molds with frustule morphologies perfectly preserved. The mineral composition dominated by Mg-calcite is explained by the low seawater temperatures where precipitation takes place, rather than by a chemical control. Methane, either dissolved in venting fluids or in the form of gas hydrate, was the obvious source of carbon of the diagenetic carbonates as evidenced by their very low ${ }^{13} \mathrm{C}$ values; some of these carbonates with very high ${ }^{18} \mathrm{O}$ values are thought to have precipitated during gas hydrate decomposition.

\section{ACKNOWLEDGEMENTS}

We thank the officers, crew and technicians of the RV l'Atalante and the ROV Victor for their work and support during the Zairov cruise in December 2000 and the Biozaire I cruise in January 2001. The Zaiango and Biozaire projects form part of an IFREMER-TOTAL partnership.

We are very grateful to Alina Stadnitskaia and Gerhard Bohrmann for their constructive and thorough comments as reviewers of the manuscript. This paper was also made possible due to the help of Soledad Garcia Gil and Alan Judd as guest editors of this special issue of GeoMarine Letters.

\section{REFERENCES}

Aloisi G, Pierre C,Rouchy JM, Foucher JP, Woodside J and the MEDINAUT Scientific Party, (2000) Methane-related authigenic carbonates of eastern Mediterranean Sea mud volcanoes and their possible relation to gas hydrate destabilisation. Earth Planet Sc Lett, 5675, 1-18 
Aloisi G, Wallmann K, Bollwerk SM, Derkachev A, Bohrmann G, Suess E (2004) The effect of dissolved barium on biogeochemical processes at cold seeps. Geochim Cosmochim Acta, $68,1735-1748$

Alperin MJ, Reeburgh WS, Whiticar MJ (1988) Carbon and hydrogen isotope fractionation resulting from anaerobic methane oxidation. Glob Biogeochem Cycles, 2, 279- 288

Anderson TF, Arthur MA (1983) Stable isotopes of oxygen and carbon and their application to sedimentologic and environmental problems. In : Stable isotopes in Sedimentary Geology, Arthur MA, Anderson TF (eds), Soc Econ Paleontol Mineral, Tulsa, Okla, USA), pp 1- 151

Baker PA, Kastner M (1981) Constraints on the formation of sedimentary dolomite. Science, 213, 214- 216

Boetius A, Ravenschlag K, Schubert CJ, Rickert D, Widdel F, Gieseke A, Amann R, Jorgensen BB, Witte O, Pfannkuche O (2000) A marine microbial consortium apparently mediating anaerobic oxidation of methane. Nature, 407, 623- 626

Bohrmann G, Greinert J, Suess E, Torres ME (1998) Authigenic carbonates from the Cascadia subduction zone and their relation to gas hydrate stability. Geology, 26, 647- 650

Bottinga Y (1969) Calculated fractionation factors for carbon and hydrogen isotope exchange in the system calcite- $\mathrm{CO}_{2}$-graphite-methane-hydrogen and water vapor. Geochim Cosmochim Acta, 33, 49- 64

Burton EA, Walter LM (1987) Relative precipitation rates of aragonite and Mg calcite from seawater: temperature or carbonate ion control ? Geology, 15, 111- 114

Campbell KA, Farmer JD, Des Marais D (2002) Ancient hydrocarbon seeps from the Mesozoic convergent margin of California: carbonate geochemistry, fluids and paleoenvironments. Geofluids, 2, 63- 94

Castellini DG, Dickens G, Snyder GT, Ruppel CD (2006) Barium cycling in shallow sediment above active mud volcanoes in the Gulf of Mexico. Chem Geol, 226, 1-30

Charlou JL, Donval JP, Fouquet Y, Ondréas H, Knoery J, Cochonat P, Levaché D, Poirier Y, Jean-Baptiste P, Fourré E, Chazallon B, the ZAIROV Leg 2 Scientific Party (2004) Physical and chemical characterization of gas hydrates and associated methane plumes in the CongoAngola Basin. Chem Geol, 205, 405- 425

Craig H (1957) Isotopic standards for carbon and oxygen and correction factors for massspectrometric analysis of carbon dioxide. Geochim Cosmochim Acta, 12, 133-149

Diaz-del-Rio V, Somoza L, Martinez-Frias J, Mata MP, Delgado A, Hernandez-Molina FJ, Lunar R, Martin-Rubi JA, Maestro A, Fernandez-Puga MC, Leon R, Llave E, Medialdea T, Vasquez JT (2003) Vast fields of hydrocarbon-derived carbonate chimneys related to the accretionary wedge/olistostrome of the Gulf of Cadiz. Mar Geol, 195, 177- 200

Elvert M, Suess E, Greinert J, Whiticar MJ (2000) Archaea mediating anaerobic methane 
oxidation in deep-sea sediments at cold seeps of the eastern Aleutian subduction zone. Org Geochem, 31, 1175- 1187

Friedman I, O'Neil JR (1971) Compilation of stable isotope fractionation factors of geochemical interest. In : Fleischer M (ed), Data of Geochemistry $\left(6^{\text {th }}\right.$ edition $)$, US Geol Surv Prof Paper, $440 \mathrm{KK}$

Fu B, Aharon P, Byerly GR, Roberts HH (1994) Barite chimneys on the Gulf of Mexico slope: initial report of their petrography and geochemistry. Geo-Mar Lett, 14, 81- 87

Gay A, Lopez M, Cochonnat P, Sultan N, Cauquil E, Brigaud F (2003) Sinuous pockmark belt as indicator of a buried turbiditic channel on the lower slope of the Congo basin, West African Margin. In : Van Rensbergen P, Hills RR, Maltman AJ, Morley CK (eds), Subsurface Sediment Mobilization, vol. 216, Geol Soc Lond Spec Publ, 173-189.

Gonfiantini R, Stichler W, Kozanski K (1995) Standards and intercomparison materials distributed by the International Atomic Energy Agency for stable isotope measurements. In: Reference and Intercomparison Materials for stable isotopes of light elements, IAEATECDOC-825, IAEA, Vienna, 13-29

Grossman EL, Ku TL (1986) Carbon and oxygen isotope fractionation in biogenic aragonite: temperature effects. Chem Geol, 59, 59- 74

Mazzini A, Ivanov MK, Parnell J, Stadnitskaia A, Cronin BT, Poludetkina E, Mazurenko L, van Weering TCE (2004) Methane-related authigenic carbonates from the Black Sea: geochemical characterisation and relation to seeping fluids. Mar Geol, 212 (1-4): 153-181

Ondréas H, Olu Le Roy K, Fouquet Y, Charlou JL, Gay A, Dennielou B, Donval JP, Fifis A, Nadalig T, Cochonat P, Cauquil E, Sibuet M (2005) Integrated "in situ" study of a deep giant pockmark on the Gabon margin during the Zaiango and Biozaire projects. Geo-Mar Lett, 25, 281-292

Orphan VJ, House CH, Hinrichs KU, McKeegan KD, DeLong EF (2001) Methaneconsuming archaea revealed by direct coupled isotopic and phylogenetic analysis. Science, 293, 484- 487

Peckmann J, Thiel V (2004) Carbon cycling at ancient methane-seeps. Chem Geol, 205, 443467

Peckmann J, Reimer A, Luth U, Hansen BT, Heinicke C, Hoefs J, Reitner J (2001) Methanederived carbonates and authigenic pyrite from the Northwestern Black Sea. Mar Geol, 177, $129-150$

Riedinger N, Kasten S, Gröger J, Franke C, Pfeifer K (2006) Active and buried authigenic barite fronts in sediments from the Eastern Cape Basin. Earth Planet Sc Lett, 241, 876- 887

Ritger S, Carson B, Suess E (1987) Methane-derived authigenic carbonates formed by subduction-induced pore-water expulsion along the Oregon/Washington margin. Geol Soc Am Bull, 98: 147-156 
Savoye B, Cochonat P, Apprioual R, Bain O, Baltzer A, 33 others (2000) Structure et évolution récente de l'éventail turbiditique du Zaïre: premiers résultats scientifiques des missions d'exploration Zaïango 1 et 2 (marge Congo-Angola). C. R. Acad. Sci. Terre Planète 331: $211-220$

Stadnitskaia A, Muyzer TG, Abbas B, Coolen MJL, Hopmans EC, Baas M, van Weering TCE, Ivanov MK, Poludetkina E, Sinninghe Damsté JS (2005) Biomarker and 16S rDNA evidence for anaerobic oxidation of methane and related carbonate precipitation in deep-sea mud volcanoes of the Sorokin Trough, Black Sea. Mar Geol 217, 67-96

Torres ME, Bohrmann G, Dubé TE, Poole FG (2003) Formation of modern and Paleozoic stratiform barite at cold methane seeps on continental margins. Geology, 31, 897-900

Tucker ME, Wright VP (1990) Carbonate sedimentology. Blackwell Scientific Publications, pp. 482.

Valentine DI, Reeburgh WS (2000) New perspectives on anaerobic methane oxidation. Env Microbiol, 2, 477- 484

Whiticar MJ (1999) Carbon and hydrogen isotope systematics of bacterial formation and oxidation of methane. Chem Geol, 161, 291- 314

Whiticar MJ, Faber E (1986) Methane oxidation in sediment and water column environmentsisotope evidence. Org Geochem, 10, 759- 768 


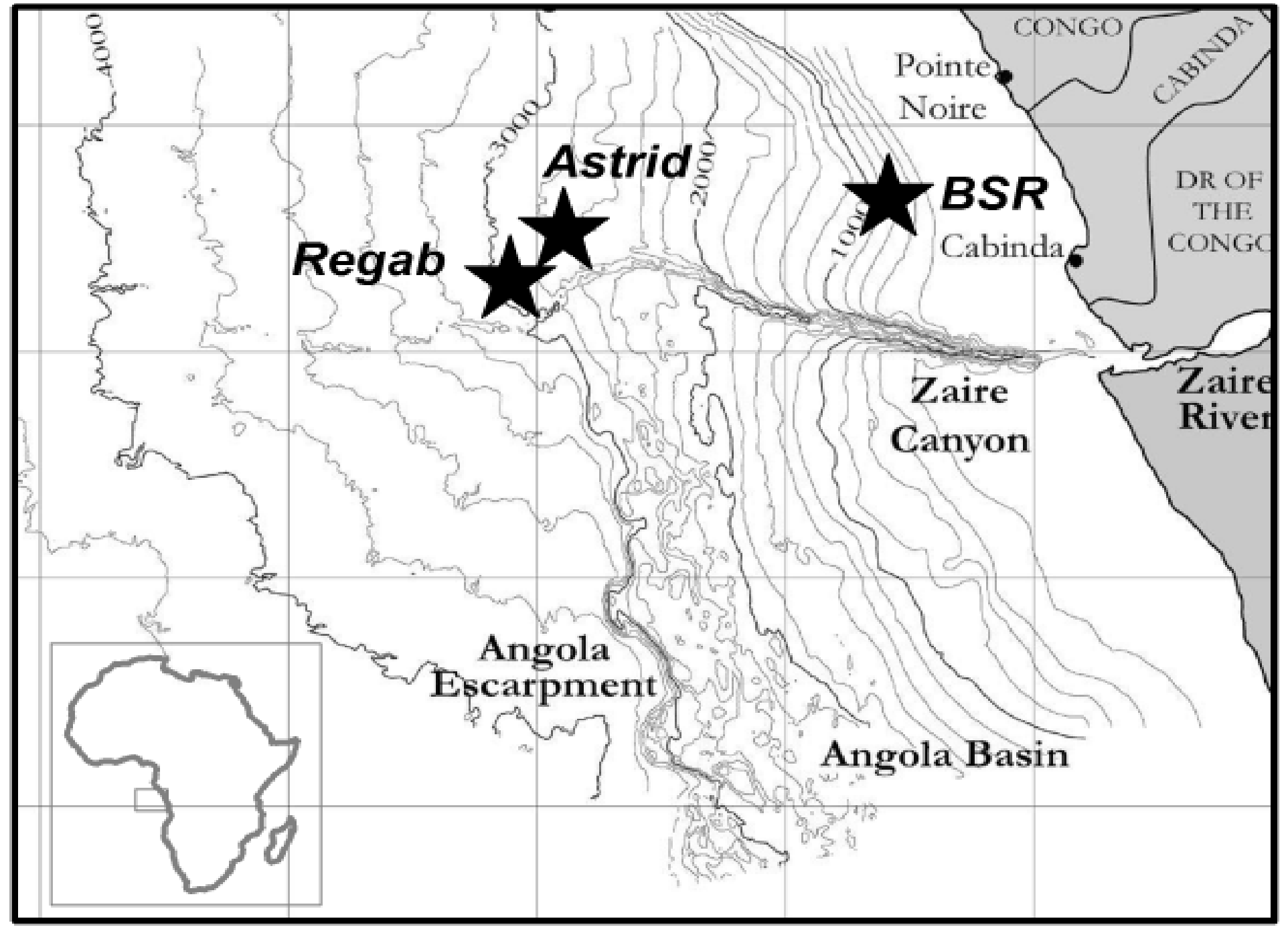

Figure 1: localisation of the studied sites 

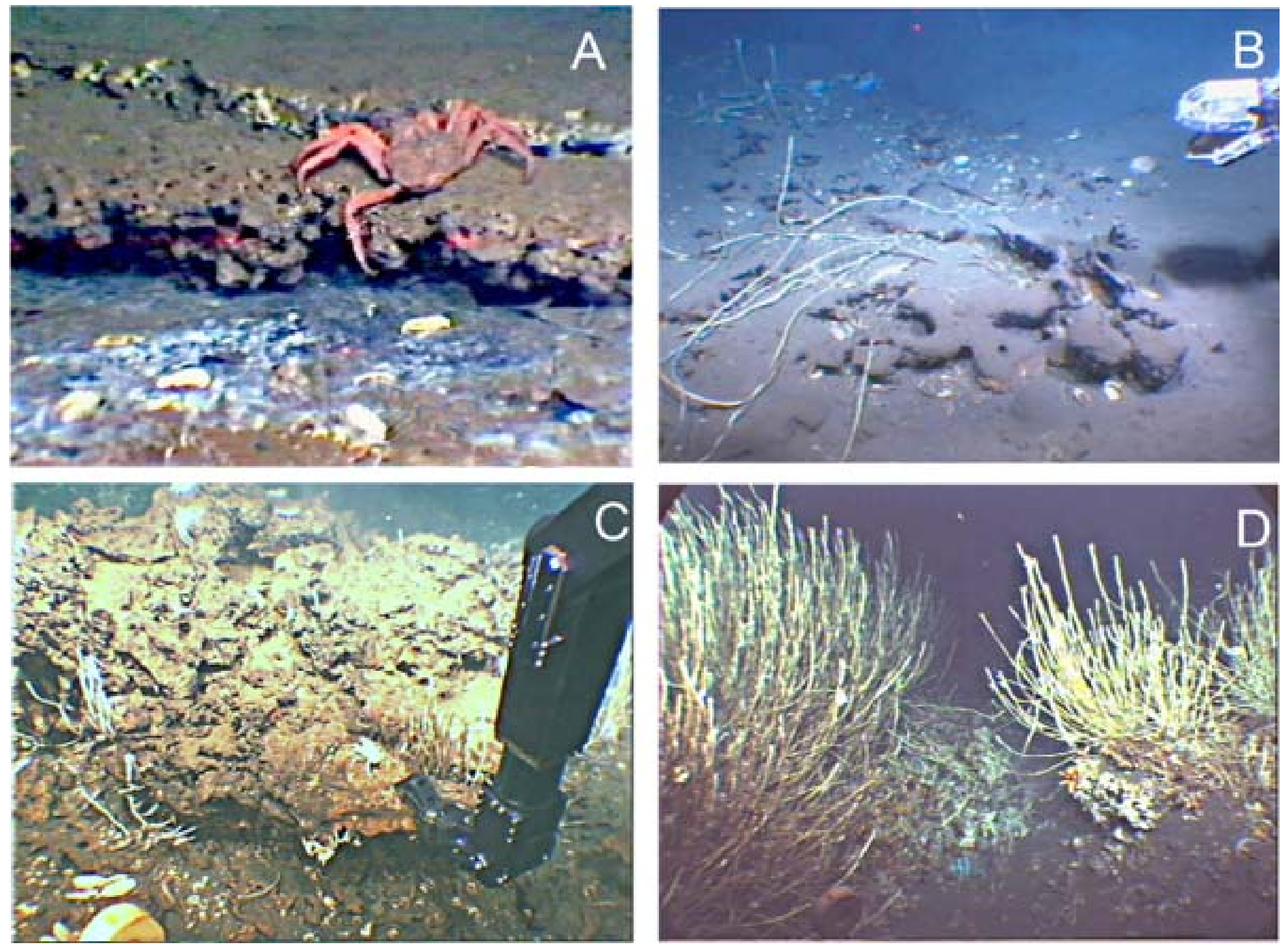

Figure 2: In situ view of seeping areas with carbonate crusts, bivalve shells and tube worms A: double layer of flat carbonate crust covering black reduced sediment with mussels (BSR site). B: Exhumation of carbonate due to erosion of overlying soft sediments by deep currents activity (Astrid site) C:Massive carbonate with some tube worms (central part of the Regab site). D: Siboglinidae tubeworms attached to a thick and hard carbonate substrate (Regab site). 

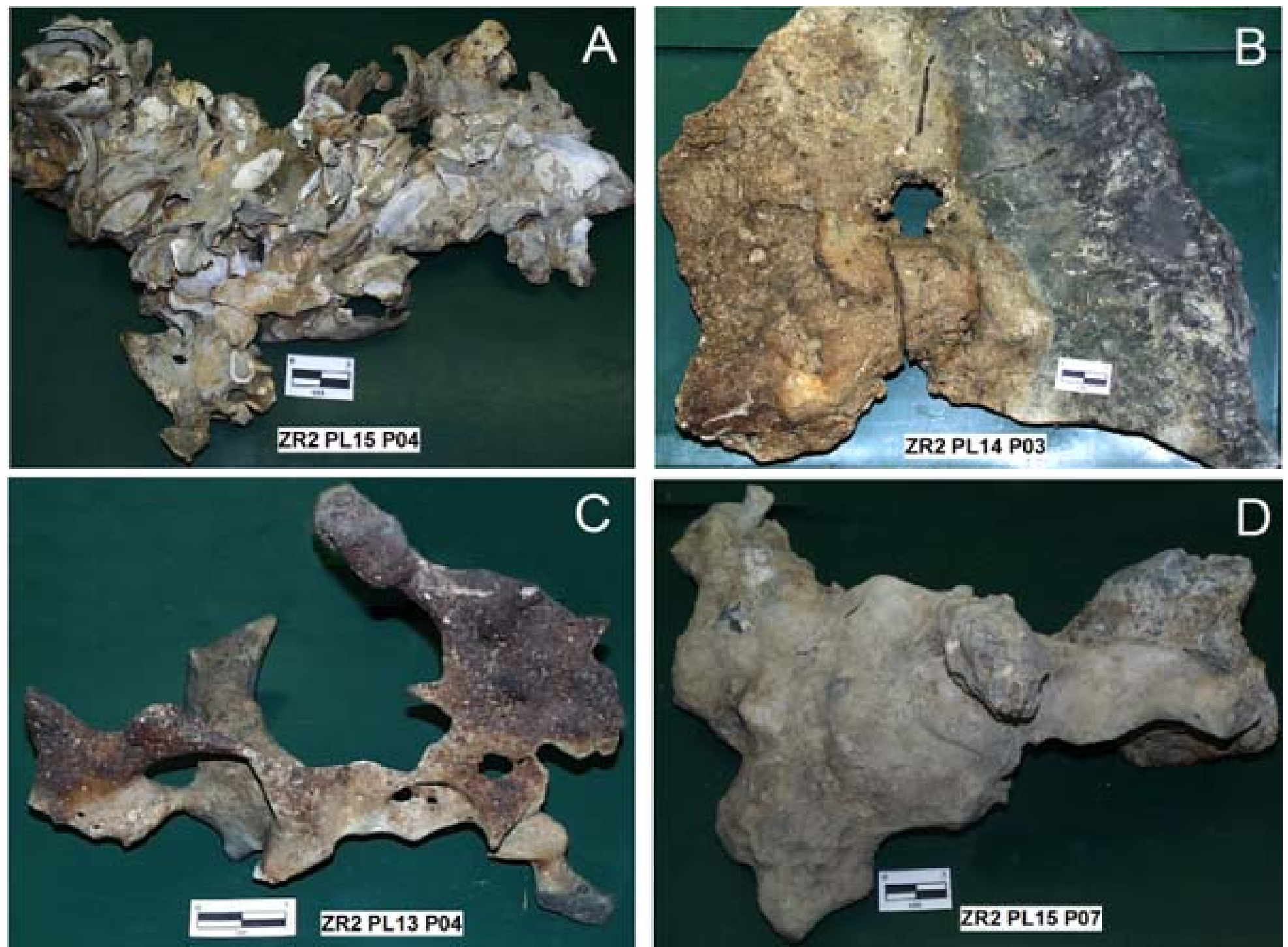

Figure 3: Macrofacies of the carbonate crusts and concretions. A: Carbonate-associated with and fossilizing bivalve shells (Regab site). B: Partly buried massive carbonate crusts (Regab site). C: Carbonates fossilizing fluid conduits within the sediment (Astrid area). D: Carbonates fossilizing fluid conduits within the sediment (Regab site). 

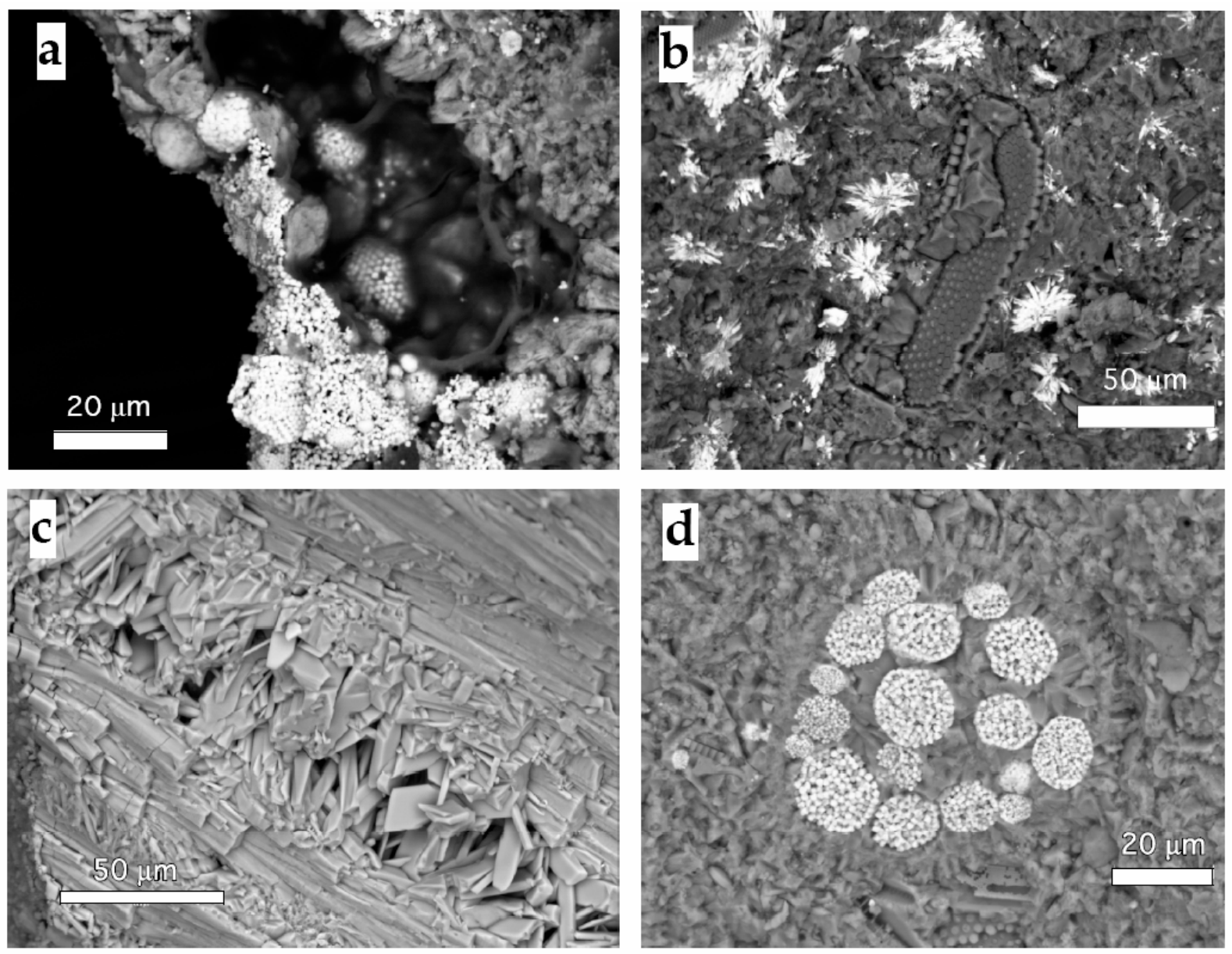

Figure 4: Microfacies : SEM photographs, back scattered electron mode

a: sample ZR2-PL 10-P01A (BSR zone, massive carbonate concretion from lithification of a conduit). Spheroids of pyrite framboids developped around a cavity covered with internal biofilms. The fine grained Mg-calcite matrix is visible on the right upper corner.

b:sample ZR2-PL 13- P04 (Astrid zone, carbonate concretion from lithification of burrows). Radiating crystals of barite within fine grained Mg-calcite. A diatom mold totally replaced by carbonate is visilbe in the enter of the photograph.

c: sample ZR2- PL 15- P01 (Regab zone, massive carbonate crust). Acicular and tabular aragonite crystals.

d: sample ZR2-PL 15- P07-1 (Regab zone, carbonate crust with oil and gas hydrate sediment). Cluster of spheroids of pyrite framboids (probably infilling a diatom mold) within the fine grained Mg-calcite matrix. 


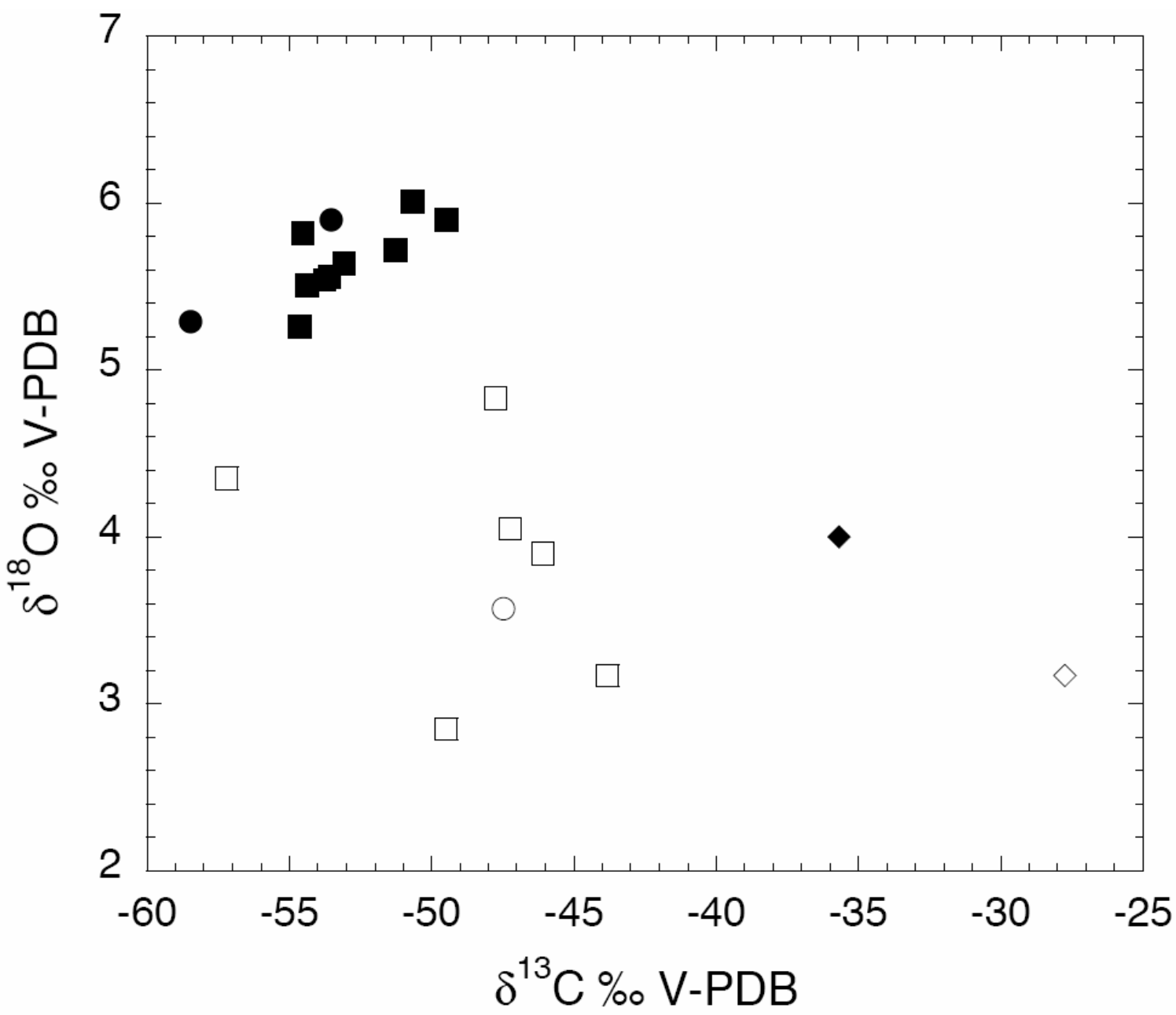

Figure 5: Oxygen and carbon isotopic compositions of the diagenetic carbonates. Filled symbols: Mgcalcite. Open symbols: aragonite + Mg-calcite. Diamonds: BSR site. Circles: Astrid site. Squares: Regab site. 


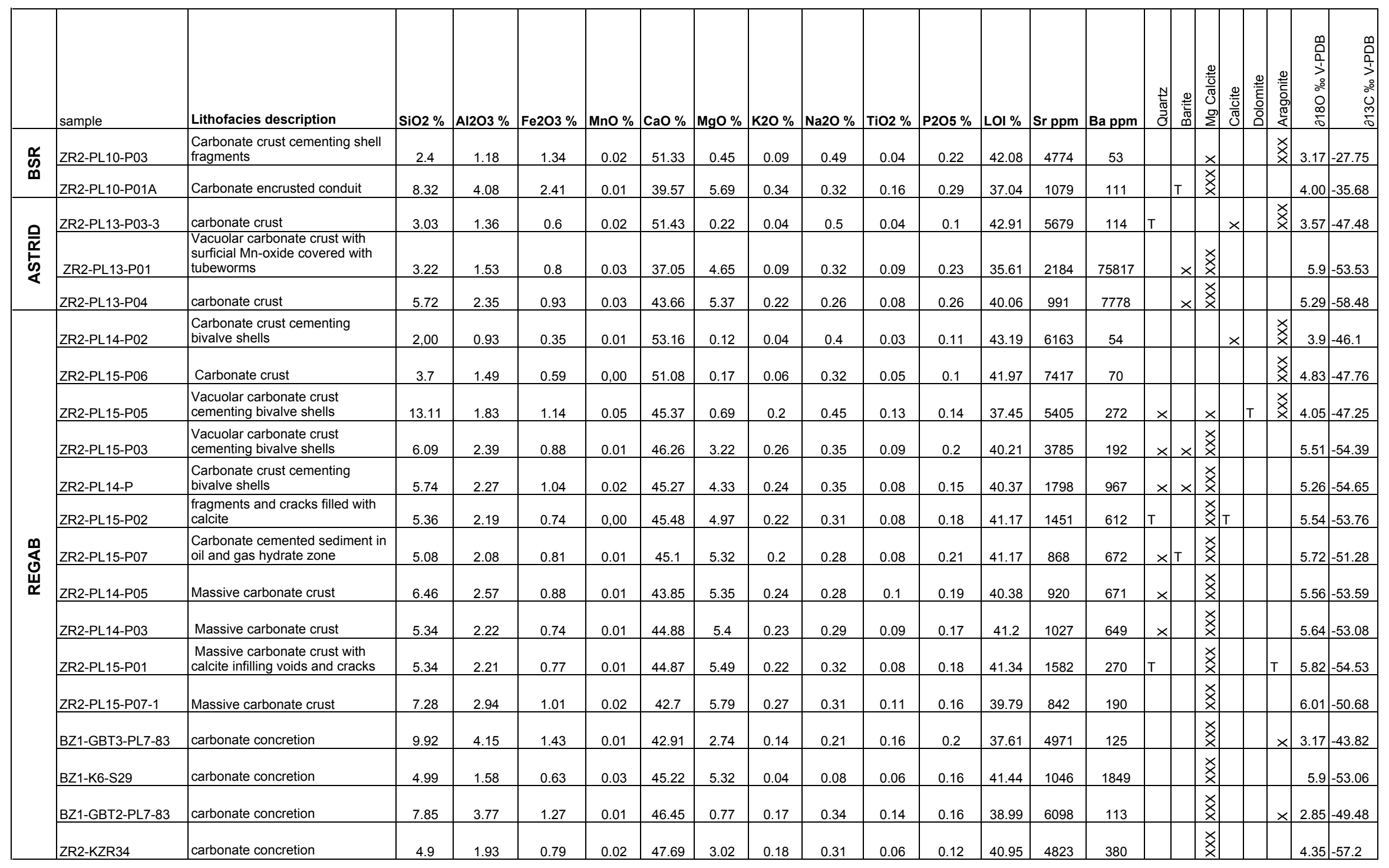

Table 1: sample description, chemical composition, mineralogy, oxygen and carbon isotopic compositions of the studied samples. The chemical compositions are expressed in weight \% of dry sediment (oxide of major elements, LOI: Lost On Ignition) and in ppm (trace elements). The abundance of minerals is semi-quantitative (T: <5\%; X: 5 to 10\%; XX: 20 to $50 \%$; XXX: > 50\%). The oxygen and carbon isotopic compositions refer to the bulk carbonate. 